lists are sent to the libraries of universities that offer graduate degrees in the social sciences, to directors of area study programmes, and to faculty members who are engaged in relevant teaching or research. The catalogue itself is available at the address below for use by students and private scholars as well as by government officials.

Beginning with this edition, the External Research Lists will appear annually and will include research in progress, and completed unpublished studies. Reports of recently completed, published research, although no longer incorporated in these lists, will continue to be entered in the catalogue where they will be available for consultation.

Further information may be obtained from the Office of External Research, Room 8733, Department of State, Washington, D.C. 20520.

\title{
Research in the Province of Darfur, Republic of the Sudan
}

A MEETING of a number of anthropologists, who had been working in various parts of Darfur Province, was held in Zalingei in December I969. Among those present were: Professor Frederic Barth of Bergen University; Professor and Mrs. Tubiana of the École Nationale des Langues Orientales Vivantes, Paris, and the Centre Nationale de Recherche Scientifique, respectively; Dr. and Mrs. Holy of Prague; Mr. Gunnar Haland of Bergen; and Mr. F. Rehfisch of the University of Khartoum.

Various government officials were invited to a formal session at which Professor Barth and Mr. Haland reported briefly on their findings during field studies among the Fur. The main purpose of this work, sponsored by the Jebel Marra Project, is to provide data on the social and economic systems of significance for the general development plan for the area. Two important factors of general interest were discussed in their presentation of data; first, the economic independence of all adult Fur characterized by absence of joint ownership property or common purse by husband and wife, and second, the selective nomadization of some Fur who were traditionally settled farmers.

Professor and Mrs. Tubiana, who had spent three months in Darfur carrying out further studies on the Zaghawa, among whom they had previously worked in the Chad Republic in 1956-7, reported further linguistic research and the collection of historical traditions, folk tales, and data on economic and social factors.

Dr. Holý, who had previously spent seven months with the Berti tribe in I96r, had just completed a further eight months in the field, this time sponsored by the International African Institute. His report centred on the basic trends of Berti economy, especially sources of cash income and its expenditure.

The participants were indebted to the Directors of the Jebel Marra Project and the officials of the local government for the help and courtesy extended to them during the meeting.

(Communicated by Mr. F. Rehfisch, University of Khartoum)

\section{'The Maghreb Digest'}

The Maghreb Digest has been published since 1962. (Annual subscription is $\$ 12$ for twelve issues.) It will be expanded from January 1966 to include an article, a chronology, and book reviews in addition to the present contents. The Digest is a monthly summary of the most important political, economic, and social issues appearing in periodic French and Arabic publications of North Africa and France. Continuing this focus, journal articles that deal with these same issues are being solicited.

Contributions, as well as books for review, are invited and should be addressed to Willard A. Beling, Editor, The Maghreb Digest, University of Southern California, Los Angeles, California 90007 . 